\title{
DISMISSAI OF SUIT BROUGHT BY A UNITED STATES CITIZEN WHERE ALTERNATIVE FORUM IS ABROAD
}

When a plaintiff goes abroad to sue he faces difficulties and expenses not incurred in a domestic suit. In addition, he faces the possibility of unfair treatment by the foreign court. Particularly sensitive to these problems where United States citizens are involved, federal courts ${ }^{1}$ have been troubled, in spite of the established doctrine of forum non conveniens, ${ }^{2}$ by the question of when a citizen should be forced to seek his remedy in a foreign forum. ${ }^{3}$

While the inconvenience faced by a United States citizen suing abroad would usually seem to be enough to prevent invocation of forum non conveniens, the language of the cases indicates that, in any event, satisfaction of the test of that doctrine ${ }^{4}$ is not sufficient. ${ }^{5}$ The courts have talked in terms of an additional re-

\footnotetext{
1 Two states have dismissed suits by citizens where the only alternative appeared to be suit outside the United States. In Universal Adjustment Corp. v. Midland Bank, 281 Mass. 303, 184 N.E. 152 (1933), the Supreme Judicial Court affirmed dismissal where the citizen was a corporation formed exclusively for the purpose of bringing suit in the United States. Texas courts have dismissed suits because of the avowed difficulty of applying Mexican law. EI Paso \& Juarez Traction Co. v. Carruth, 255 S.W. 159 (Tex. Comm'n of Appeals, 1923); Jones v. Mexican Cent. Ry. Co., 68 S.W. 186 (Tex. Civ. App., 1902); Mexican Nat. R. Co. v. Jackson, 33 S.W. 857 (Tex. S. Ct., 1896). But cf. Mexican Cent. Ry. Co. v. Mitten, 36 S.W. 282 (Tex. Civ. App., 1896).

2 Gulf Oil Corp. v. Gilbert, 330 U.S. 501 (1947).

3 This question, of course, only arises where no other forum is available in the United States. Thus, for example, in Stewart v. Godoy-Sayan, 153 F.Supp. 544 (S.D. N.Y., 1957), dismissing suit against a Cuban defendant, the only remaining forum was in Cuba, for (1) the defendant was not amenable to process in any state other than New York; and (2) the New York state courts could not obtain personal jurisdiction over a non-resident in the state attending another civil action to which he was a party. New England Industries v. Margiotti, 270 App.Div. 488, 60 N.Y.S.2d 430 (1st Dept., 1946).

While one district has held that a citizen has an indefeasible constitutional right of access to United States courts of admiralty, The Epsom, 227 Fed. 158 (W.D. Wash., 1905); The Neck, 138 Fed. 144 (W.D. Wash., 1905); The Troop, 117 Fed. 557 (D. Wash., 1902); The Fails of Keltie, 114 Fed. 357 (D. Wash., 1902), the majority position is that no such right exists. Muller \& Co. v. Swedish American Line, 224 F.2d 806 (C.A.2d, 1955), cert. denied 350 U.S. 903 (1955); Cerro De Pasco Copper Corp. v. Knut Knutsen, O.A.S., 187 F.2d 990 (C.A.2d 1951); United States Merchants' \& Shippers' Ins. Co. v. A/S Den Norske Afrika Og Australie Line, 65 F.2d 392 (C.A.2d, 1933); Murillo, Ltda. v. The Bio Bio, 127 F.Supp. 13 (S.D. N.Y., 1955), aff'd 227 F.2d 519 (C.A.2d, 1955); Libby, McNeill \& Libby v. Bristol Line of S.S., 41 F.Supp. 386 (S.D. N.Y., 1941); Insurance Co. of North America v. British India Steam Nav. Co., 38 F.Supp. 47 (E.D. La., 1941); The Albergen, 223 Fed. 443 (S.D. Ga., 1915); The Welhaven, 55 Fed. 80 (S.D. Ala., 1892); The Marie, 49 Fed. 286 (D. Ore., 1892); The Burchard, 42 Fed. 608 (S.D. Ala., 1890); The Salomoni, 29 Fed. 534 (S.D. Ga., 1886). The United States Supreme Court has declined to pass on the question, Swift \& Co. v. Compania Caribe, 339 U.S. 684, 697 (1949). In non-admiralty cases, the courts have also held that no constitutional right exists. Vanity Fair Mills v. T. Eaton Co., 234 F.2d 633 (C.A.2d, 1956), cert. denied 352 U.S. 871 (1956); Stewart v. Godoy-Sayan, 153 F.Supp. 544 (S.D. N.Y., 1957).

' "It is often said that the plaintiff may not, by choice of an inconvenient forum, 'vex,' 'harass,' or 'oppress' the defendant by inflicting upon him expense or trouble not necessary to his own right to pursue his remedy. But unless the balance is strongly in favor of the defendant, the plaintiff's choice of forum should rarely be disturbed." Gulf Oil Corp. v. Gilbert, 330 U.S. 501, 508 (1947).
} 
quirement, a showing of "injustice" or "manifest injustice" to the defendant. They have not, however, gone on to explain what they mean. Thus, the only guide to the requirements for dismissal is the fact situations where dismissal was granted.

One line of cases involving dismissal of citizen plaintiffs has dealt with contracts limiting jurisdiction over disputes arising under the contract to foreign forums. Generally courts in the United States have been unwilling specifically to enforce such contracts, ${ }^{8}$ but, more recently, federal courts have held that if such a contract is not unreasonable in the setting of a particular case the action will be dismissed. ${ }^{9}$ Since the settings of these cases were the same as cases where the grounds for forum non conveniens were present but jurisdiction was retained, ${ }^{10}$ it may be argued that the "reasonableness" restriction requires a showing of forum non conveniens grounds, ${ }^{11}$ the existence of the contract then satisfying the requirement of showing "manifest injustice" to the defendant. It would be preferable, however, to regard these cases as holding that the existence of the contract will, without more, prevent the plaintiff from suing in a federal court. Such a contract can be considered an addition to the shipping tariff or selling price; there is no reason to regard this area as one in which the courts should interfere with the parties' bargaining. Under this interpretation the language dealing with reasonableness can be regarded as an anchor to windward in the abandonment of precedents refusing enforcement of jurisdictional contracts.

5 Burt v. Isthmus Development Co., 218 F.2d 353 (C.A.5th, 1955); Wheeler v. Societe Nationale Des Chemins, 108 F.Supp. 652 (S.D. N.Y., 1952); Latimer v. S/A Industrias Reundias F. Matarazzo, 91 F.Supp. 469 (S.D. N.Y., 1950); The Saudades, 67 F.Supp. 820 (E.D. Pa., 1946).

- Wheeler v. Societe Nationale Des Chemins, 108 F.Supp. 652 (S.D. N.Y., 1952); Latimer v. S/A Industrias Reundias F. Matarazzo, 91 F.Supp. 496 (S.D. N.Y., 1950); The Saudades, 67 F.Supp. 820 (E.D. Pa., 1946).

${ }^{7}$ Burt v. Isthmus Development Co., 218 F.2d 353 (C.A.5th, 1955).

${ }^{8}$ Rest., Contracts $\$ 558$ (1932); Stumberg, Conflict of Laws 270 (2d ed., 1951). But see Rest., Conflict of Laws $\$ 617$ (1934). The reasons given for this position seem to be that such contracts oust the courts of their jurisdiction and that matters of remedy, being created and regulated by law, cannot be altered by agreement. 25 Fordham L. Rev. 133 (1956), noting Muller \& Co. v. Swedish American Line, 224 F.2d 806 (C.A.2d, 1955), cert. denied 350 U.S. 903 (1955).

${ }^{9}$ Muller \& Co. v. Swedish American Iine, 224 F.2d 806 (C.A.2d, 1955), cert. denied 350 U.S. 903 (1955); Murillo Ltda. v. The Bio Bio, 127 F.Supp. 13 (S.D. N.Y., 1955) aff'd 227 F.2d 519 (C.A.2d, 1955). See also 25 Fordham L. Rev. 133 (1956), noting Muller \& Co. v. Swedish American Line, supra.

${ }^{10}$ Compare cases cited in note 9 supra, with cases cited in note 5 supra.

11 "[T] he factors determinative of an inconvenient forum largely turn upon identical ones involved in the unreasonableness of a stipulation limiting the tribunal to which resort may be had, and accordingly both the ground of unreasonable stipulation and that of inconvenient forum should be appraised together." Murillo Ltda. v. the Bio Bio, 127 F.Supp. 13, 15 (S.D. N.Y., 1955). 
Another line of cases appears to make the citizen's right to sue a foreigner in an inconvenient federal forum turn on whether the plaintiff was suing in his own right or in the right of a foreigner. ${ }^{12}$ In United States Merchants' \& Shippers' Ins. Co. v. A/S Den Norske Afrika Og Australie Line ${ }^{13}$ an American insurance company insured the goods of a Dutch shipper transported by a Norwegian carrier under a bill of lading providing that all questions arising under the bill of lading were to be decided in Oslo. The goods were destroyed in transit and, after paying the Dutch shipper, the insurance company libelled the Norwegian line in a federal district court in New York. The district court dismissed the action $^{14}$ and the Court of Appeals affirmed in an opinion by Judge Learned Hand. While this decision was undoubtedly sound since the defendant made his contract with the shipper and the plaintiff knew or should have known about the bill of lading provision before insuring the goods, there was unfortunate emphasis in the opinion upon the derivative character of the plaintiff's right. ${ }^{15}$ In Stewart v. Godoy-Sayan ${ }^{16}$ a federal district court relied upon this emphasis to dismiss a suit by United States citizens against a Cuban defendant. The plaintiffs were executors under the will of an American stockholder of a Cuban corporation. The remainder of the stock was held by the defendant, president of the corporation. Although the suit alleged that the defendant's misappropriation of the corporation's assets impaired the value of the plaintiffs' stock, the court held that the real harm was to the corporation and that the plaintiffs' suit was derivative in nature. The court then reasoned that, while it should not ordinarily use the doctrine of forum non conveniens to dismiss an action brought by a citizen, since the original transaction in this case involved two foreigners, the Merchants' \& Shippers' Ins. Co. case authorized dismissal.

12 United States Merchants' \& Shippers' Ins. Co. v. A/S Den Norske Afrika Og Australie Line, 65 F.2d 392 (C.A.2d, 1933); Stewart v. Godoy-Sayan, 153 F.Supp. 544 (S.D. N.Y., 1957); Jefferson Ins. Co. v. Cia. Colonial De Navegacao, 121 F.Supp. 828 (S.D. N.Y., 1954); Latimer v. S/A Industrias F. Matarazzo, 91 F.Supp. 469 (S.D. N.Y., 1950); The Saudades, 67 F.Supp. 820 (E.D. Pa., 1946). These cases cannot be explained on the ground that the statute intended to prevent the invocation of jurisdiction through assignments made for that purpose, 62 Stat. 935 (1948), 28 U.S.C. $\$ 1359$ (1950), requires application of the plaintiff-inhis-own-right doctrine. Just as in domestic diversity cases, the court can examine all the circumstances and conditions which surround the making of the assignment or transfer in order to determine whether jurisdictional grounds do in fact exist. Steinberg v. Toro, 95 F.Supp. 791 (D. P.R., 1951). An involuntary assignment could be easily ascertained and it is difficult to comprehend how a business transaction such as the sale and purchase of insurance could have been entered into for the purpose of invoking the jurisdiction of a particular forum. Admittedly a voluntary assignment would cause more difficulty; but if a plaintiff wants to sue in a federal court he bears the burden of showing that its jurisdiction is properly invoked. McNutt v. General Motors Acceptance Corp., 298 U.S. 178 (1936).

${ }^{13} 65$ F.2d 392 (C.A.2d, 1933).

11 The Tricolor, 1 F.Supp. 934 (S.D. N.Y., 1932).

15 "Courts are maintained to give redress primarily to their own citizens; it is enough if these [courts] conform to the conditions set upon their jurisdiction. [This] would be conclusive if the libellant sued in his own right." 65 F.2d 392, 392-93 (C.A.2d, 1933).

${ }^{15} 153$ F.Supp. 544 (S.D. N.Y., 1957). 
It is questionable, however, whether this reasoning is correct. The Merchants' $\&$ Shippers' Ins. Co. case can best be explained by the bill of lading provision; but, in any event, it would seem that the broadest interpretation that can be given to Judge Hand's opinion is that, where the original transaction was such that the foreign defendant could not reasonably have expected to defend a suit in the plaintiff's chosen forum, it would be unjust, where the grounds for forum non conveniens were present, to make him do so. The Stewart case does not present this situation. The deceased and the defendant were the only stockholders and the defendant could reasonably have expected that if jurisdiction could be obtained any transaction between him and the corporation would be challenged in the United States by the deceased or his executors.

Finally, the Second Circuit Court of Appeals has affirmed the dismissal of a suit by a citizen plaintiff to restrain the infringement of a trademark by a foreign defendant, where the forum was inconvenient and where there was a possibility of conflict with the administrative and judicial officers of Canada. ${ }^{17}$ The Canadian Registrar of Trade-Marks had registered the disputed trademark in the defendant's name and had refused subsequent registration to the plaintiff on the ground that it interfered with the defendant's prior registration. The plaintiff alleged trademark infringement and unfair competition in Canada; and, since the court found that the Lanham Act had no extraterritorial application, the decisive question in the case under conflict of laws principles was the validity of the defendant's Canadian registration under Canadian law. Emphasizing that the plaintiff could raise the question of validity affirmatively or as a defense in Canadian courts, that the defendant had acted pursuant to a privilege conferred by the law of the place where the acts occurred, and that courts have refused to determine the validity of acts of a foreign sovereign done within its borders, the court stated that the power to enjoin the defendant "should be exercised with great reluctance when the exercise of such power is fraught with possibilities of discord and conflict with the authorities of another country."18

The opinion of the court appears correct. An American judgment might have been in conflict with a Canadian act of state..$^{19}$ Also, it would be inequitable to punish a defendant for violating an injunction where his behavior was required by a foreign court. ${ }^{20}$ And yet, if an injunction were to provide for such a

17 Vanity Fair Mills v. T. Eaton Co., 234 F.2d 633 (C.A.2d, 1956), cert. denied 352 U.S. 871 (1957).

18 Id., at 647.

19 E.g., American Banana Co. v. United Fruit Co., 213 U.S. 347 (1909).

20 For an illustration of the type of conflict that can arise see United States $v$. Imperial Chemical Industries, 105 F.Supp. 215 (S.D. N.Y., 1952) and British Nylon Spinners v. Im- 
contingency there would seem to be little sense, where the contingency is likely to occur, in allowing suit in the American court. The only question is whether dismissal should also require the usual showing of an inconvenient forum. The language of the court implies that it does $^{21}$ but it would seem that the above reasoning is just as cogent whether or not the defendant can show inconvenience sufficient to warrant dismissal under the usual application of the doctrine of forum non conveniens.

Thus, an examination of the cases reveals that, except for the Stewart case, United States citizens have had suits dismissed only where the grounds for forum non conveniens were present and there was a contract or a possibility of conflict with foreign courts. Excepting possibly a broad reading of Merchants' \& Shippers' Ins. Co. ${ }^{22}$ an analysis of these cases indicates that the forum non conveniens grounds should not have been necessary. No cases have indicated whether a showing by the defendant of inconvenience greater than that usually required to satisfy forum non conveniens would alone be sufficient.

But even more basic than what constitutes "manifest injustice" is the question of whether a foreign defendant should have to demonstrate something more than the usual grounds of forum non conveniens to obtain dismissal. Admittedly, as has been argued, ${ }^{23}$ a citizen plaintiff pays taxes to support the courts, but this argument is not persuasive. The citizen obtains from the courts other benefits that the foreigner does not receive-those benefits derived from living in an ordered society. State courts applying forum non conveniens to their own citizens must not have found this tax payer argument convincing. ${ }^{24}$ It would seem that the real reason behind the courts' behavior must be a fear of unfair treatment for United States citizens as plaintiffs in foreign courts. However, the probability of reciprocal behavior by foreign courts when a United States citizen is a defendant should limit such paternal protection to cases where the citizen plaintiff can demonstrate a danger of prejudice.

perial Chemical Industries, [1953] 1 Ch. D. 19, where a United States district court directed a British corporation to perform certain acts which an English court later enjoined in order to enforce an English contract.

21 "We are convinced that the balance of convenience is strongly in favor of the defendant, but it is unnecessary for ... us to rely solely on that ground." Vanity Fair Mills v. T. Eaton Co., 234 F.2d 633, 646 (C.A.2d, 1956) (emphasis added).

22 See text at 380 supra.

${ }^{23}$ Bickel, The Doctrine of Forum Non Conveniens as Applied in the Federal Courts in Matters of Admiralty, 35 Cornell L.Q. 12, 44-45 (1949); Forum Non Conveniens-Trial Court's Discretion Limited When Forum Non Conveniens Would Force American Plaintiff to Sue in Foreign Courts, 103 U. of Pa. L. Rev. 830, 832 (1955), noting Burt v. Isthmus Development Co., 218 F.2d 353 (C.A.5th, 1955).

${ }^{24}$ E.g., Pietraroia v. New Jersey \& H.R. Ry. \& F. Co., 131 App.Div. 829, 116 N.Y.Supp. 249 (1st Dept., 1909); but cf. Zeikus v. Florida East Coast Ry. Co. 144 App.Div. 91, 128 N.Y.Supp. 933 (1st Dept., 1911). 